\title{
Oxalate biofilm formation in mural paintings due to microorganisms - A comprehensive study
}

\author{
Tânia Rosado ${ }^{\mathrm{a}, \mathrm{b}}$, Milene Gil ${ }^{\mathrm{a}, \mathrm{b}}$, José Mirão ${ }^{\mathrm{a}, \mathrm{c}}$, António Candeias ${ }^{\mathrm{a}, \mathrm{b}}$, \\ Ana Teresa Caldeira ${ }^{\mathrm{a}, \mathrm{b}, *}$ \\ a HERCULES Laboratory, Évora University, Largo Marquês de Marialva 8, 7000-809 Évora, Portugal \\ b Évora Chemistry Centre and Chemistry Department, Évora University, Rua Romão Ramalho 59, 7000-671 Évora, Portugal \\ ' Évora Geophysics Centre and Geosciences Department, Évora University, Rua Romão Ramalho 59, 7000-671 Évora, Portugal
}

\section{A R T I C L E I N F O}

Article history:

Received 6 November 2012

Received in revised form

20 June 2013

Accepted 24 June 2013

Available online 10 July 2013

Keywords:

Biodeterioration

Microbial communities

Metabolic activity

Biofilms

Oxalates

Raman microscopy

\begin{abstract}
A B S T R A C T
Oxalate film formation is a pathology that often occurs in mural paintings and may result from the concomitant action of microorganisms and environmental conditions.

Low Choir of the Convent of Nossa Senhora da Saudação (Portugal) has mural paintings with an extraordinary beauty, which over time have been suffered polychromy degradation and biofilm formation, presenting an ideal case study to investigate the role and impact of microorganisms in the biodeterioration process.

Bacterial populations, filamentous fungi belonging to the genera Cladosporium, Penicillium, Nectria and yeast strain of the genera Rhodotorula were isolated from these wall paintings. The penetration of fungal hyphae in the microstructure of mortars, observed by scanning electron microscopy, seems to be responsible for cracking and detachments in some areas of the painting. The study revealed that the veils on the surface of the paintings are essentially oxalates and that these biofilms are caused by metabolic activity of bacterial communities. Furthermore, the colour alteration of green areas due to microorganisms was detected by Raman microscopy, in real samples and under in vitro conditions, being the result of the metabolic activity of microorganisms present on the paintings, which promote calcium oxalates formation over the malachite paint layers.
\end{abstract}

(c) 2013 Elsevier Ltd. All rights reserved.

\section{Introduction}

Biodeterioration is an undesirable process, triggered by living organisms, which can affect cultural heritage and economically important materials (Rojas et al., 2009). This field is a relevant issue in the conservation of art works and monuments that represent a widely diversified group of ecological niches for various organisms (Capodicasa et al., 2010). Colonisation of art works by microorganisms such as bacteria, fungi, algae and lichens, can be influenced by environmental conditions such as humidity, temperature, light and by chemical factors like the nature of the substrate (Garg et al., 1995; Ciferri, 1999; Heyrman and Swings, 2003; Pangallo et al., 2009). Some authors suggest bacteria as the first agents in the colonisation of mural paintings, because they have reduced

\footnotetext{
* Corresponding author. Évora Chemistry Centre and Chemistry Department, Colégio Luís António Verney, Rua Romão Ramalho n 59, 7000-671, Évora, Portugal. Tel.: +351 266745311; fax: +351266745303.

E-mail address: atc@uevora.pt (A.T. Caldeira).
}

nutritional needs, providing organic matter to the next colonizers. On the other hand, the growth of biological agents such as fungi is identified as a determinant factor in the degradation of the murals (Garg et al., 1995; Rölleke et al., 1996). Their proliferation is enhanced in situations of high humidity and temperature. As reported in the literature a wide variety of fungi of the genera Penicillium, Cladosporium, Alternaria, Curvularia, Dreschlera, Chaetomium, Fusarium, Trichoderma, Gliomastix, Aureobasidium, are the most abundant in the mural paintings (Garg et al., 1995; Gorbushina et al., 2004; Sterflinger, 2010). The microbial activity can cause structural and aesthetics damage in the paintings. Development of fungi in mural paintings can induce discoloration and deterioration of its surface, leading to the appearance of stains that alter the colour of the paint layer, on the other hand hyphae penetration may lead to detachment of fragments, bacterial growth is frequently associated to the formation of biofilms, promoting discoloration of the pigments (Garg et al., 1995; Ciferri, 1999; Gorbushina and Petersen, 2000; Milanesi et al., 2006; Guiamet et al., 2011). 